J. Appl. Glycosci., 57, 7-12 (2010)

(C) 2010 The Japanese Society of Applied Glycoscience

Regular Paper

\title{
Rheological Characteristics of Alginate Isolated from Commercially Cultured Nemacystus decipiens (Itomozuku)
}

\author{
(Received April 10, 2009; Accepted August 25, 2009) \\ Takeshi Teruya, ${ }^{1}$ Yukihiro Tamaki, ${ }^{1}$ Teruko Konishi ${ }^{1}$ and Masakuni Tako ${ }^{1, *}$ \\ ${ }^{1}$ Department of Bioscience and Biotechnology, University of the Ryukyus \\ (1, Senbaru, Nishihara, Okinawa 903-0213, Japan)
}

\begin{abstract}
The non-Newtonian behavior and storage modulus of an alginate isolated from Nemacystus decipiens which had been harvested in Uruma City (Okinawa, Japan) in aqueous solutions were investigated. Gelation occurred at a concentration of $0.5 \%$ of the alginate on addition of a mixed solution of $\mathrm{NaCl}(0.1 \%), \mathrm{KCl}$ $(0.1 \%)$ and $\mathrm{CaCl}_{2}(0.1 \%)$ at room temperature $\left(25^{\circ} \mathrm{C}\right)$. The flow curves, at $35^{\circ} \mathrm{C}$, of the alginate showed plastic behavior at various concentrations. The storage modulus of the alginate increased with an increase in concentration and decreased gradually with an increase in temperature up to $50^{\circ} \mathrm{C}$, which was estimated to be a transition temperature; then it, on the contrary, increased gradually with a further increase in the temperature and showed the maximum value at a temperature of 60,70 and $65^{\circ} \mathrm{C}$ at $0.3,0.5$ and $0.7 \%$, respectively. The storage modulus of the alginate showed a large value even in the presence of urea $(4.0 \mathrm{M})$. The storage modulus of the alginate showed a very large value at the pH range of 6.0-7.2, but very small at pH 4.0. However, a comparable large storage modulus was observed in the alkaline range (pH 9.0-11.0). Intra- and intermolecular $\mathrm{Ca}^{2+}$-bridges may play a dominant role in the gel formation of alginate molecules in the presence of $\mathrm{Ca}^{2+}$ ions with ionic bonding and electrostatic forces of attraction. The hydrophobic interaction may take place on the L-guluronic acid-rich homopolymeric blocks of the alginate molecules in the high temperature range.
\end{abstract}

Key words: alginate, $\mathrm{Ca}^{2+}$-induced association, ionic bonding, Nemacystus decipiens

In the course of rheological studies of polysaccharides, we have discussed the molecular origin for their rheological characteristics and proposed a gelation mechanism for K-carrageenan, ${ }^{1,2}$ l-carrageenan, ${ }^{3)}$ agarose (agar), ${ }^{4)}$ gellan gum, ${ }^{5)}$ amylose $^{6}$ and curdlan ${ }^{7}$ at the molecular level in aqueous solutions. On the basis of the gelation mechanism proposed, we have gained insight into the principles of polysaccharide gels. ${ }^{8}$

In particular, intra- and intermolecular $\mathrm{Ca}^{2+}$ bridges have been involved in 1 -carrageenan molecules. ${ }^{3,9)}$ The intramolecular $\mathrm{Ca}^{2+}$ bridge may take place between sulfate groups substituting on anhydro-D-galactose and Dgalactose residues. Each cation is coordinated with two sulfate groups with ionic bonding. The bridge proposed has been developed into an intermolecular association mechanism of the $\mathrm{Ca}$ salt of $\mathrm{l}$-carrageenan in aqueous solution. As the Brownian motion and kinetic energy of solvent and polymer molecules decrease upon cooling, intermolecular $\mathrm{Ca}^{2+}$ bridges have also occurred on different molecules having electrostatic forces of attraction.

Alginic acid is the major structural polysaccharide found in brown seaweeds and represents the commercial source from which alginate is extracted for use as gelling agents and stabilizers in the food and other industries. ${ }^{10)}$ Alginic acid is a linear polymer composed of $(1 \rightarrow 4)$ linked $\beta$-D-mannuronic acid and $\alpha$-L-guluronic acid units arranged in either homo- or heteropolymeric sequence. ${ }^{11)}$ The gelling characteristics of an alginate are strongly in-

${ }^{*}$ Corresponding author (Tel., Fax. +81-98-895-8814, E-mail: tako @eve.u-ryukyu.ac.jp). fluenced by its uronic acid composition, i.e. the ratio of mannuronic acid residues to guluronic acid residues.

We have investigated rheological characteristics of commercial sodium alginate in aqueous solution. ${ }^{12,13)}$ The flow curves of the alginate solution shifted over high shear stress with an increase in concentration, but showed Newtonian behavior up to $0.75 \%(\mathrm{w} / \mathrm{v})$ and shearthinning behavior at a concentration of $1.0 \%$. The storage modulus of the alginate showed a small value even at a low temperature $\left(0^{\circ} \mathrm{C}\right)$ and decreased gradually with an increase in temperature. The results indicated that there was less secondary association in sodium induced alginate molecules in aqueous solution.

In a previous study, we investigated rheological properties of well characterized commercial alginates $(45 \mathrm{M}, 45 \mathrm{G}$ and 45, molar ratio of D-mannuronic acid to L-guluronic acid was $0.98,0.21$ and 0.61 , and molecular weight of polymers was 124,000: Kibun Food Chemipha Co., Ltd., Tokyo, Japan) with the addition of a mixed solution of $\mathrm{NaCl}$ and $\mathrm{CaCl}_{2 .}{ }^{13)}$ Gelation occurred at a concentration of $0.5 \%$ of alginates at room temperature. The storage modulus of $45 \mathrm{M}$ alginate rich in D-mannuronic acid was scarcely changeable with increasing temperature up to $60^{\circ}$ $\mathrm{C}$, which was estimated to be a transition temperature; then it decreased rapidly with a further increase in the temperature. Though the storage modulus of $45 \mathrm{G}$ alginate rich in L-guluronic acid decreased gradually with increasing temperature up to $60^{\circ} \mathrm{C}$, which was also estimated to be a transition temperature, then it, on the contrary, increased with a further increase in temperature. The storage modulus of 45 alginate decreased gradually with an in- 
crease in temperature until $50^{\circ} \mathrm{C}$; then it decreased rapidly. Intra- and intermolecular $\mathrm{Ca}^{2+}$-bridges with ionic bonding and electrostatic forces of attraction through the carboxyl groups might play a dominant role in the gel formation of alginate molecules in the presence of $\mathrm{Ca}^{2+}$ ions.

We have recently isolated an alginate about $1.6 \%$ in yield based on the wet seaweed from commercially cultured Nemacystus decipiens Kuckuck (named in Japan Itomozuku), which had been harvested in Uruma City, Okinawa Prefecture, Japan. ${ }^{14)}$ The alginate consisted of Dmannuronic acid and L-guluronic acid which was identified by ${ }^{1} \mathrm{H}$ - and ${ }^{13} \mathrm{C}-\mathrm{NMR}$ spectroscopy, the molar ratio of both residues being estimated to be $0.72: 1.00$. The molecular mass of the alginate was estimated to be about 1.5 $\times 10^{5}$.

We report herein the non-Newtonian behavior and dynamic viscoelasticity of the alginate isolated from $N$. decipiens in the presence of $\mathrm{Na}^{+}$and $\mathrm{Ca}^{2+}$ ions. The rheological properties are analyzed with respect to its association characteristics in comparison with those of commercial alginates in aqueous solution. ${ }^{13)}$

\section{MATERIALS AND METHODS}

Materials. N. decipiens, which was commercially cultured on nets $(1.5 \times 20 \mathrm{~m})$ in the sea off Uruma City (Henza Island, Okinawa Prefecture, Japan) from November 1998 to May 1999, was used in this study. A wet seaweed sample (100 g) was homogenized with double its weight of $0.2 \mathrm{M} \mathrm{HCl}(200 \mathrm{~g})$, stirred at room temperature for $3 \mathrm{~h}$, centrifuged at $23,000 \times \mathrm{g}$ for $20 \mathrm{~min}$ and filtered through Celite $545 .^{14,15)}$

The residual precipitate was washed with distilled water and then suspended in a $0.3 \% \quad \mathrm{Na}_{2} \mathrm{CO}_{3}$ solution at room temperature for $3 \mathrm{~h}$ to extract the alginate. The extract was neutralized with $0.1 \mathrm{M} \mathrm{HCl}$ and then gelled by the addition of $2.0 \% \mathrm{CaCl}_{2}$. The gelatinous precipitate was separated by centrifugation at $23,000 \times \mathrm{g}$ for $20 \mathrm{~min}$. This precipitate was washed with distilled water, and then dissolved in a $1.0 \mathrm{M} \mathrm{NaOH}$ solution. The resulting solution was filtered through Celite 545 and then dialyzed overnight against distilled water. In the presence of $\mathrm{NaCl}(200$ $\mathrm{mg}$ ), ethanol ( 2 vols.) was added and the precipitate was dried in vасио. The crude alginate $(2.0 \mathrm{~g})$ was dissolved in $300 \mathrm{~mL}$ of distilled water and passed through a column of Amberlite IR-120 ( $\left.\mathrm{H}^{+}\right)$to deionize it, before being neutralized with $0.5 \mathrm{M} \mathrm{NaOH}$. The solution was dialyzed against distilled water and then freeze-dried (1.6 g).

Methods. Solutions of alginate were prepared by dissolving the sodium alginate $(90,150$ and $210 \mathrm{mg}$ ) in hot water $\left(20 \mathrm{~mL}\right.$ at $\left.70^{\circ} \mathrm{C}\right)$ and adding a mixed solution (10 $\mathrm{mL})$ of $\mathrm{NaCl}(30 \mathrm{mg}), \mathrm{KCl}(30 \mathrm{mg})$ and $\mathrm{CaCl}_{2}(30 \mathrm{mg})$ to reach final alginate concentration of $0.3,0.5$ and $0.7 \%$, respectively. Measurements were performed after stirring the solutions at $70^{\circ} \mathrm{C}$ for $30 \mathrm{~min}$.

Viscosity at various shear rates $\left(1.19-95.01 \mathrm{~s}^{-1}\right)$ and dynamic viscoelasticity at a steady angular velocity (3.77 $\mathrm{rad} / \mathrm{s}$ ) were determined with a rheogoniometer (IR-103, Iwamoto Seisakusho Co., Ltd., Japan) consisting of a coaxial cylinder $(1.8 \mathrm{~cm}$ diam.) and rotating outer cylinder (2.2 cm diam.), $6.0 \mathrm{~cm}$ long. The temperature of the sam- ple was controlled by circulating oil from a Thermo-cool (LCH-130F, Toyo Co., Ltd., Japan) over a temperature ranging from 0 to $80^{\circ} \mathrm{C}$ raised at a rate of $1{ }^{\circ} \mathrm{C} / \mathrm{min}$ in steps. Shear rate $(\tau)$, shear stress $(\dot{\gamma})$ and viscosity $(\eta)$ were calculated by an equation of Margules. ${ }^{16)}$ The yield value was estimated by the extrapolation of flow curve to shear-stress line. Storage modulus $\left(G^{\prime}\right)$ and dynamic viscosity $\left(\eta^{\prime}\right)$ were calculated by a modification of Markovitz's equation. ${ }^{17)}$ The loss tangent was calculated from the relationship $\tan \delta=G^{\prime} / G^{\prime \prime}$ where $G^{\prime \prime}$ is the loss modulus $(\omega \eta)$ and $\omega$ is angular velocity of the outer cylinder.

\section{RESULTS}

\section{Characteristic of alginate solutions.}

A rapid precipitation of the alginate occurred upon addition of $10 \mathrm{~mL}$ of $0.3 \% \mathrm{CaCl}_{2}$ solution (w/v) into an aqueous solution $(20 \mathrm{~mL})$ of the alginate at concentrations of $0.3,0.5$ and $0.7 \%(90,150$ and $210 \mathrm{mg} / 30 \mathrm{~mL})$ at room temperature. Such a phenomenon was also observed in well characterized commercial alginate $45 \mathrm{M}, 45 \mathrm{G}$ and 45 solutions, ${ }^{13)}$ but not observed in l-carrageenan where intra- and intermolecular $\mathrm{Ca}^{2+}$ bridges have been accomplished between sulfate groups on different molecules (Scheme 1). ${ }^{3,9)}$ The precipitation might be caused by the formation of much more intense intra- and intermolecular $\mathrm{Ca}^{2+}$ bridges with ionic bonding and electrostatic forces of attraction within and between alginate molecules. In this condition, almost all of the $\mathrm{Na}^{+}$cations might be replaced by $\mathrm{Ca}^{2+}$ cations, resulting in precipitation. Accordingly, to make a gel or gel-like solution for rheological measurements, a mixed salts solution $(30 \mathrm{mg}$ and $30 \mathrm{mg}$ of $\mathrm{NaCl}$ and $\mathrm{CaCl}_{2} / 10 \mathrm{~mL}$; corresponding to final salt concentrations of 0.1 and $0.1 \%$, respectively) was added to an alginate solution $(20 \mathrm{~mL})$ to reach a final alginate concentration of $0.3,0.5$ and $0.7 \%$ (90, 150 and $210 \mathrm{mg}$ ).

\section{Flow behavior.}

Although alginate prepared from $N$. decipiens at a concentration of $0.5 \%(\mathrm{w} / \mathrm{w})$ did not gel alone, it gave a gel upon the addition of a mixed salts solution $(0.1 \% \mathrm{NaCl}$ and $\left.0.1 \% \mathrm{CaCl}_{2}\right)$ at room temperature $\left(25^{\circ} \mathrm{C}\right)$. Such gelformation was also observed in well characterized commercial alginate $45 \mathrm{M}, 45 \mathrm{G}$ and 45 with addition of the salts solution. ${ }^{13)}$ As a gelation occurred at $25^{\circ} \mathrm{C}$, the flow

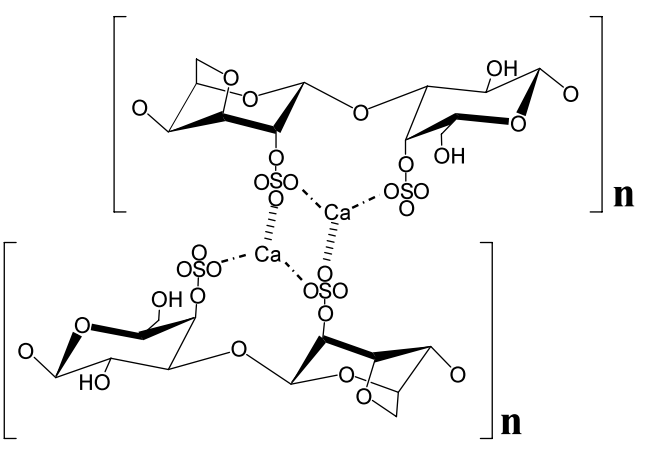

Scheme 1. Possible intra- and intermolecular $\mathrm{Ca}^{2+}$ bridges of $\mathrm{l}$ carrageenan molecules in aqueous solution.

Association: -.-.-.-, ionic bonding; 11111111, electrostatic forces of attraction. 


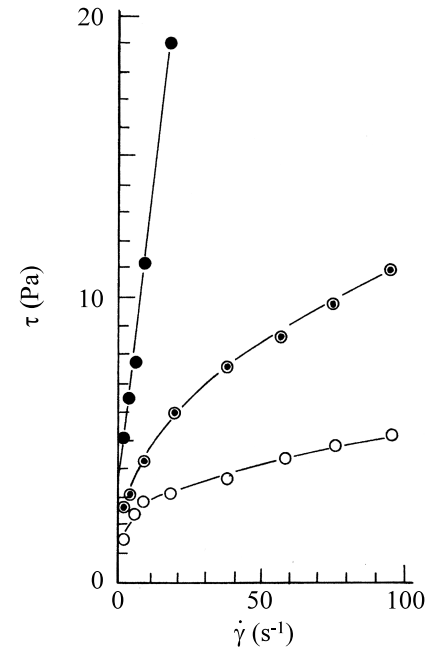

Fig. 1. Flow curves, at $35^{\circ} \mathrm{C}$, of the alginate isolated from $N$. decipiens at various concentrations.

Concentration: $\bigcirc, 0.3 \%$; $\bullet, 0.5 \% ; \bullet, 0.7 \%$.

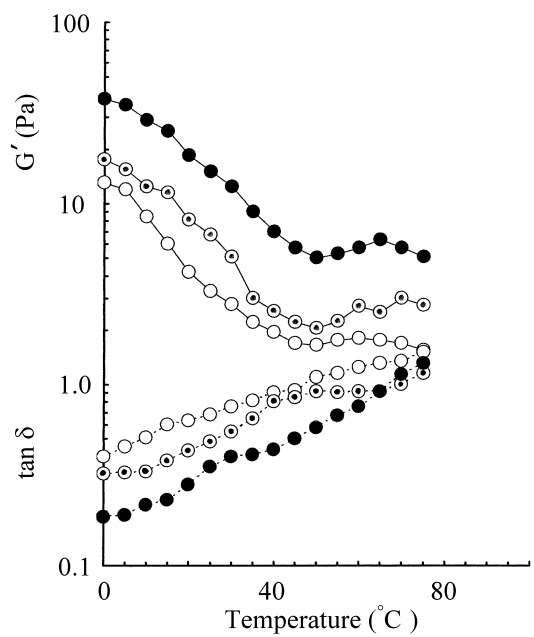

Fig. 2. Effect of temperature on the storage modulus and $\tan \delta$ of the alginate isolated from $N$. decipiens at an angular velocity of $3.77 \mathrm{rad} / \mathrm{s}$ and at various concentrations.

Concentration: $\bigcirc, 0.3 \% ; \bullet, 0.5 \% ; \bullet, 0.7 \%$. The solid lines refer to storage modulus and dotted lines to $\tan \delta$.

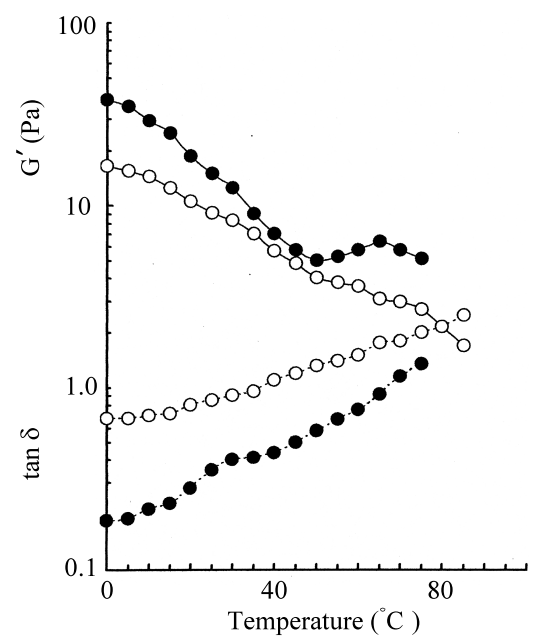

Fig. 3. Effect of temperature on the storage modulus and $\tan \delta$ of the alginate isolated from $N$. decipiens at a concentration of $0.7 \%$ with the addition of urea $(4.0 \mathrm{M})$ at an angular velocity of $3.77 \mathrm{rad} / \mathrm{s}$. in salts solution; $\bigcirc$, with addition of urea $(4.0 \mathrm{M})$. curves were measured at $35^{\circ} \mathrm{C}$.

The flow curves for the alginate at a concentration of $0.3 \%$ was approximated to plastic behavior and shifted over higher shear stress with increasing concentration, as shown in Fig. 1. The yield value was estimated to be 1.0, 2.3 and $4.2 \mathrm{~Pa}$ at $0.3,0.5$ and $0.7 \%$, respectively. The flow curves of alginate solution (without salts) showed shear-thinning behavior even at a concentration of $1.0 \%$ and shifted to low shear stress (not shown in the figure). The results indicate that the alginate molecules are involved in a secondary association in the presence of $\mathrm{Ca}^{2+}$ cations.

\section{Dynamic viscoelasticity.}

Gelation occurred for the alginate at a concentration of $0.3 \%$ on cooling. The storage modulus of the alginate increased with an increase in concentration at $0^{\circ} \mathrm{C}$, as shown in Fig. 2. The storage modulus of the solution decreased gradually with an increase in temperature up to $50^{\circ} \mathrm{C}$, which was estimated to be a transition temperature; then it, on the contrary, increased gradually with a further increase in the temperature and showed a maximum value at 60,70 and $65^{\circ} \mathrm{C}$ at a concentration of $0.3,0.5$ and $0.7 \%$, respectively. A sigmoid curve was observed during the increase in the temperature at various concentrations. A very large sigmoid curve was observed in a solution of $0.7 \%$. This indicates that a conformational change occurs above the transition temperature $\left(60,70\right.$ and $\left.65^{\circ} \mathrm{C}\right)$. Such an increase in the storage modulus in the high temperature range was also observed in a mixed salts solution of commercial alginate $45 \mathrm{G}$ rich in L-guluronic acid $(\mathrm{M} / \mathrm{G}$ : $0.21) .{ }^{13)}$ A sigmoid curve was also observed in our preceding papers in aqueous solutions of native xanthan, ${ }^{18-20)}$ rhamsan $^{21)}$ and S-6572) gums. The dynamic viscosity also showed a similar profile as that of the storage modulus and showed a sigmoid curve during the increase in temperature at various concentrations (not shown in figure). A very large sigmoid curve was observed in a solution of $0.7 \%$. The results indicate that the alginate molecules are involved in intramolecular association in addition to an intermolecular association in the presence of $\mathrm{Ca}^{2+}$ ions. ${ }^{3,9)}$

On the other hand, the $\tan \delta$ value decreased from 0.42 to 0.18 with increase in concentration of the alginate from 0.3 to $0.7 \%$ at low temperature $\left(0^{\circ} \mathrm{C}\right)$. The $\tan \delta$ value for the $0.5 \%$ solution increased with an increase in temperature up to $50^{\circ} \mathrm{C}$; then it decreased a little with a further increase in temperature. However, the value increased a little again above $70^{\circ} \mathrm{C}$ and showed a weak sigmoid curve. The $\tan \delta$ value increased gradually with an increase in temperature at 0.3 and $0.7 \%$. The result indicates that the alginate molecules associate tightly even at a concentration of $0.3 \%$, because the $\tan \delta$ showed a low value $(0.41)$.

The storage modulus of the alginate at $0.7 \%$ concentration in the presence of urea $(4.0 \mathrm{M})$ showed a value $(18.0$ $\mathrm{Pa}$ ) of less than about $1 / 2$ that of aqueous solution at low temperature $\left(0^{\circ} \mathrm{C}\right)$, as shown in Fig. 3. However, the value in the presence of urea $(4.0 \mathrm{M})$ solution corresponded to that of $0.3 \%$ alginate solution (Fig. 2) having a value of $10.5 \mathrm{~Pa}\left(0^{\circ} \mathrm{C}\right)$. The storage modulus of the alginate solution in the presence of urea decreased more slowly than 
that without urea solution with an increase in temperature. The result indicates that a secondary association remained even in the presence of urea $(4.0 \mathrm{M})$ in the alginate molecules. The storage modulus of the solution decreased gradually with an increase in temperature.

The effect of $\mathrm{pH}$, at $25^{\circ} \mathrm{C}$, on the storage modulus and $\tan \delta$ of the alginate at a concentration of $0.7 \%$ was measured. The storage modulus of the alginate showed large values in the neutral and weak acid range, $\mathrm{pH} 6.0^{-7.2}$ and comparable large values in the alkaline range, $\mathrm{pH} 9.0^{-}$ 11.0, the solution of which was prepared with the addition of $50 \mathrm{mM} \mathrm{NaOH}$, as shown in Fig. 4. However, the storage modulus showed a lower value at a $\mathrm{pH}$ of 4.0 with the addition of a $50 \mathrm{~mm} \mathrm{HCl}$ solution. On the other hand, $\tan \delta$ showed a very small value, $0.105-0.13$, in the neutral and weak acid range, but showed a large value in the acid and alkaline range. The lower storage modulus at $\mathrm{pH}$ 4.0 with the addition of $50 \mathrm{mM} \mathrm{HCl}$ indicates that a secondary association of the alginate molecules dissociates where a significant amount of $\mathrm{Ca}^{2+}$ ions had been replaced by $\mathrm{H}^{+}$ions.

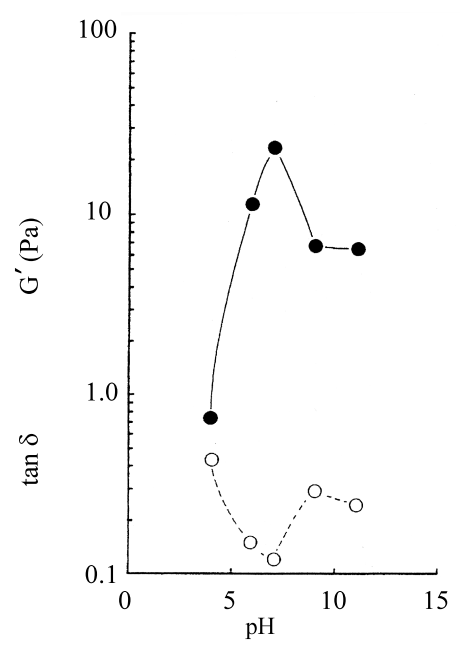

Fig. 4. Effect of $\mathrm{pH}$, at $3.77 \mathrm{rad} / \mathrm{s}$, on the storage modulus and $\tan \delta$ of the alginate isolated from $N$. decipiens at a temperature of $25^{\circ} \mathrm{C}$.

The $\mathrm{pH}$ value was adjusted with the addition of $50 \mathrm{~mm} \mathrm{HCl}$ or $\mathrm{NaOH}$. The solid line refers to storage modulus and dotted line to $\tan \delta$.

\section{DISCUSSION}

The effects of $\mathrm{Ca}^{2+}$ ions on the ordered conformation and gel formation of an alginate isolated from commercially cultured $N$. decipiens have been confirmed in this study. The storage modulus at a concentration of $0.3,0.5$ and $0.7 \%$ solution of the alginate decreased gradually with increased temperature up to $50^{\circ} \mathrm{C}$, which was estimated to be a transition temperature, the profile of which is in agreement with that of commercial alginates 45 and $45 \mathrm{G}$; however, it increased with a further increase in temperature and showed a sigmoid curve. The phenomenon suggests that an intramolecular association is involved in the alginate molecule. ${ }^{8,1823-26)}$ Thus we propose a possible mode of an intramolecular $\mathrm{Ca}^{2+}$ bridge between a carboxyl group of D-mannuronic acid and an adjacent carboxyl group of L-guluronic acid residue, as illustrated in Scheme 2. Each cation is coordinated with two carboxyl groups with ionic bonding. The bridge proposed has been developed into an intermolecular association mechanism of the $\mathrm{Ca}$ salt of alginate in aqueous solution: intermolecular $\mathrm{Ca}^{2+}$ bridges may also occur on different molecules having electrostatic forces of attraction (Scheme 2). Scheme 2 explains that a little decrease of the storage modulus is observed with the addition of urea $(4.0 \mathrm{M})$ in $0.7 \%$ alginate solution at low temperature $\left(0^{\circ} \mathrm{C}\right)$ and slightly stable values are maintained during an increase in the temperature. Intramolecular hydrogen bonding may also be involved between a hydroxyl group at C-3 of Dmannuronic acid residue and an adjacent hemiacetal oxygen atom of L-guluronic acid residue, as illustrated in Scheme 2. The intramolecular hydrogen bonding proposed may be stable during increases in temperature even in the high temperature range as that in the agarose molecule. ${ }^{4)}$

An increase in storage modulus in the high temperature range was also observed in a solution of a commercial alginate rich in L-guluronic acid $(45 \mathrm{G} ; \mathrm{M} / \mathrm{G}$ ratio, 0.21 ) where a hydrophobic interaction might play a dominant role. ${ }^{13)}$ This suggests that the alginate isolated from $N$. decipiens may also be involved in a hydrophobic interaction in the high temperature range like that in the alginate 45 G.

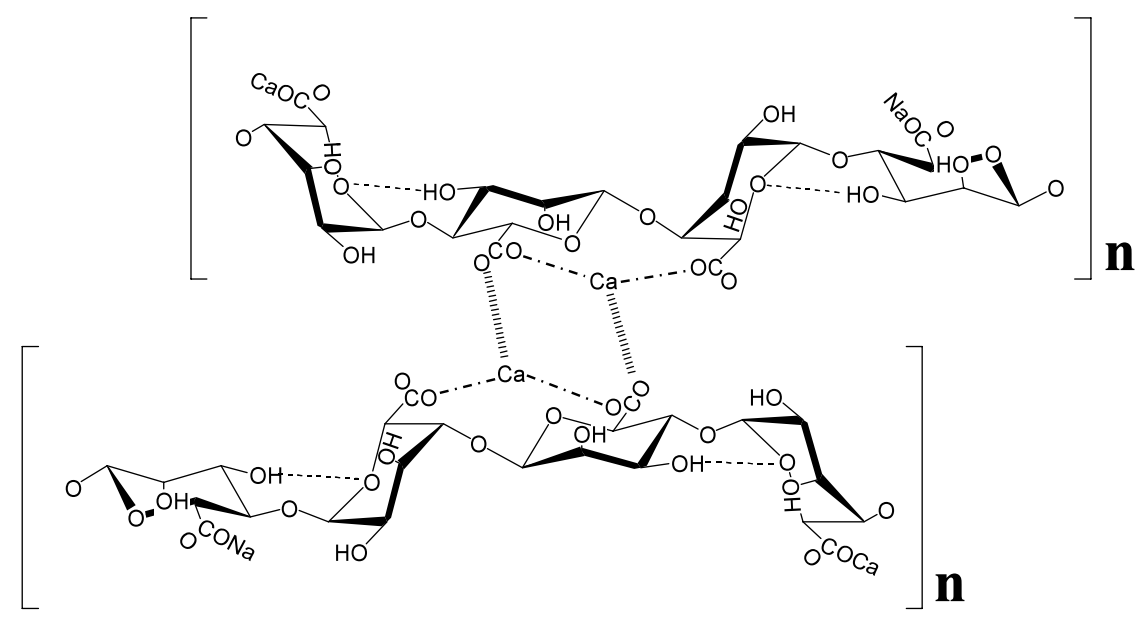

Scheme 2. Possible intra- and intermolecular associations of the alginate isolated from $N$. decipiens.

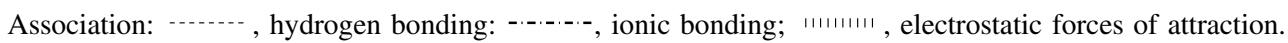


Though the molar ratio of $\mathrm{D}$-mannuronic acid to $\mathrm{L}$ guluronic acid of commercial alginate 45 (0.61) is comparable with that of the alginate (0.72) from $N$. decipiens, the storage modulus decreased gradually with increase in the temperature and a sigmoid curve was not observed. ${ }^{13)}$ This suggests that the alginate molecules isolated from $N$. decipiens may be involved in L-guluronic acid homopolymeric block regions ${ }^{27,28)}$ where an intermolecular hydrophobic interaction may be built up in the high temperature range $>50^{\circ} \mathrm{C}$.

As reported previously, hydrophobic interaction, in the high temperature range, might be involved in curdlan molecules, ${ }^{7)}$ the structure of which was $\beta$-1,3-linked glucan, ${ }^{29)}$ where the storage modulus stayed constant with increasing temperature up to $40^{\circ} \mathrm{C}$, then decreased rapidly. However, after the temperature reached $55^{\circ} \mathrm{C}$, the storage modulus increased gradually with a further increase in the temperature. This indicated that two-step conformational transitions occurred at both temperatures $\left(40\right.$ and $\left.55^{\circ} \mathrm{C}\right)$ on curdlan molecules in aqueous solution. On the basis of the curious rheological characteristics of curdlan, we proposed a possible mode of intermolecular hydrogen bonding, which might be involved in the low temperature range < $40^{\circ} \mathrm{C}$, and hydrophobic interaction, in the high temperature range $>55^{\circ} \mathrm{C}$, between hydroxyl groups of C- 6 of Dglucosyl residues and between $\mathrm{CH}_{2}$ groups of $\mathrm{C}-6$ of $\mathrm{D}-$ glucosyl residues on different molecules. ${ }^{7}$

The gelation mechanism of curdlan proposed suggests that after dissociation of the ionic bonding, which may be formed on the alginate molecules through $\mathrm{Ca}^{2+}$ cations at low temperature, a hydrophobic interaction may be built up at temperatures above $50^{\circ} \mathrm{C}$ between L-guluronic acid residues on different molecules of the alginate, association sites of which are not known yet.

Thus the rheological characteristics of alginate isolated from $N$. decipiens may be useful for developments not only in industrial application, but also in understanding the biological functions.

$N$. decipiens also contains a fucoidan of about $0.5 \%$ in yield based on the wet alga. ${ }^{30)}$ The fucoidan consists of Lfucose, D-galactose and sulfuric acid in the molar ratio of 1.0:0.1:1.0. Fucoidans seem to have biological activities such as anti-coagulant, ${ }^{31)}$ anti-thrombin, ${ }^{32)}$ anti-tumor, ${ }^{33,34)}$ anti-HIV infection, ${ }^{35)}$ and immunomodulating ${ }^{36)}$ which might be caused by the high number of substituting sulfate groups. Thus, alginate and fucoidan can be produced on an industrial scale from $N$. decipiens cultured in Okinawa, Japan. ${ }^{14,30)}$

\section{REFERENCES}

1 ) M. Tako and S. Nakamura: Indicative evidence for a conformational transition in $\kappa$-carrageenan from studies of viscosityshear rate dependence. Carbohydr. Res., 155, 200-205 (1986).

2 ) M. Tako and S. Nakamura: Synergistic interaction between $\kappa$ carrageenan and locust-bean gum in aqueous media. Agric. Biol. Chem., 50, 2817-2822 (1986).

3 ) M. Tako, S. Nakamura and Y. Kohda: Indicative evidence for a conformational transition in l-carrrageenan. Carbohydr. Res., 161, 247-254 (1987).

4 ) M. Tako and S. Nakamura: Gelation mechanism of agarose. Carbohydr. Res., 180, 277-284 (1988).
5 ) M. Tako, A. Sakae and S. Nakamura: Rheological properties of gellan gum aqueous media. Agric. Biol. Chem., 53, 771776 (1989).

6 ) M. Tako and S. Hizukuri: Evidencce for conformational transition in amylose. J. Carbohydr. Chem., 14, 613-622 (1995).

7 ) M. Tako and I. Hanashiro: Evidence for conformational transition in curdlan. Polymer Gels Networks, 5, 241-250 (1997).

8 ) M. Tako: Structural principles of polysaccharide gels. J. Appl. Glycosci., 47, 49-53 (2000).

9 ) L. Lin, M. Tako and F. Hongo: Molecular origin for rheological characteristics of 1 -carrageenan isolated from Togekirinsai (Eucheuma serra). Food Sci. Technol. Res., 7, 176-180 (2001).

10) K. Clare: Algin. in Industrial Gums, R.L. Whistler and J.N. BeMiller, eds., Academic Press, New York, pp. 105-143 (1993).

11) A. Heyraud, C. Gey, C. Leonard, C. Rochas, S. Girond and B. Kloareg: NMR spectroscopy analysis of oligoguluronates and oligomannuronates prepared by acid or enzymatic hydrolysis of homopolymeric blocks of alginic acid. Carbohydr. Res., 289, 11-23 (1996).

12) M. Tako, T. Nagahama and D. Nomura: Flow characteristics of the viscous polysaccharide produced by Coryneform Bacteria Strain C-8. Nippon Nogeikagaku Kaishi, 51, 397-403 (1977).

13) M. Tako and Y. Kohda: Calcium induced association characteristics of alginate. J. Appl. Glycosci., 44, 153-159 (1987).

14) M. Tako, S. Kiyuna and F. Hongo: Isolation and characterization of alginic acid from commercially cultured Nemacystus decipiens (Itomozuku). Biosci. Biotechnol. Biochem., 65, 654657 (2001).

15) M. Tako, E. Yoza and S. Tohma: Chemical characterization of acetyl fucoidan and alginate from commercially cultured Cladosiphon okamuranus. Bot. Mar., 43, 393-398 (2000).

16) J. Harris: More detail analysis of the coaxial cylinder viscometer. in Rheology and non-Newtonian flow, Longman, J. H. ed., Longman, New York, pp. 28-33 (1977).

17) H. Markovitz: A property of bressel function and its application to the theory of two rheometers. J. Appl. Phys., 23, 10701077 (1952)

18) M. Tako, T. Nagahama and D. Nomura: Non-Newtonian flow and dynamic viscoelasticity of xanthan gum. Nippon Nogeikagaku Kaishi, 51, 513-518 (1977).

19) M. Tako and S. Nakamura: Evidence for intramolecular associations in xanthan molecules in aqueous media. Agric. Biol. Chem., 53, 1941-1946 (1989).

20) M. Tako: Molecular origin for rheological characteristics of xanthan gum. ACS Symp. Ser., 489, 268-281 (1992).

21) M. Tako: Molecular origin for thermal stability of rhamsan gum in aqueous media. Biosci. Biotechnol. Biochem., 57, 1182-1184 (1993).

22) M. Tako: Molecular origin for the thermal stability of S-657 polysaccharide. Polymer Gels Networks, 2, 358-371 (1994).

23) M. Tako and S. Hizukuri: Molecular origin for the thermal stability of rice amylopectin. J. Carbohydr. Chem., 16, 655-666 (1997).

24) M. Tako and S. Hizukuri: Molecular origin for the thermal stability of Koshihikari rice amylopectin. Food Res. Int., 33, 3540 (2000).

25) M. Tako, S. Thoma, T. Taira and M. Ishihara: Gelation mechanism of deacetylated rhamsan gum. Carbohydr. Polym., 54, 279-285 (2003).

26) M. Tako and H. Tamaki: Molecular origin for the thermal stability of S-88 gum produced by Pseudomonus ATCC 31554 . Polym. J., 37, 498-505 (2005).

27) E.R. Morris, D.A. Rees and D. Thom: Chiroptical and stoichiometric evidence of a specific primary dimerisation process in alginate gelations. Carbohydr. Res., 66, 145-154 (1978).

28) H. Zheng: Interaction mechanism in sol-gel transition of alginate solutions by addition of divalent cations. Carbohydr. Res., 302, 97-104 (1997).

29) T. Harada, A. Misaki and H. Saito: Curdlan: A bacterial gelforming 3-1,3-glucan. Arch. Biochem. Biophys., 124, 292-298 (1968). 
30) M. Tako, T. Nakada and F. Hongo: Chemical characterization of fucoidan from commercially cultured Nemacystus decipiens (Itomozuku). Biosci. Biotechnol. Biochem., 63, 1813-1815 (1999).

31) S. Colliec,. A.M. Fischer, J. Tapon-Bretaudiere, C. Boisson, P. Durand and J. Jozefoniez: Anticoagulant properties of a fucoidan fraction. Thrombosis Res., 64, 143-154 (1991).

32) T. Nishino and T. Nagumo: The relationship between the sulfate content and the antithrombin activity of and $\alpha-(1-2)-$ fucoidan purified from a commercial fucoidan fraction. Bot. Mar., 38, 187-193 (1995).

33) H. Itoh, H. Amano and H. Zhuaug and T. Mizuno: Antitumor activity and immunological properties of marine algal polysaccharides, especially fucoidan, prepared from Sargassum thumbergii of phaeophyceae. Anticancer Res., 13, 2045-2052 (1993).

34) T. Teruya, T. Konishi, S. Uechi, H. Tamaki and M. Tako: Anti-proliferative activity of oversulfated fucoidan from commercially cultured Cladosiphon okamuranus TOKIDA in U937 cells. Int. J. Biological Macromol., 41, 221-226 (2007).

35) M.C. McClure, D. Whitby, C. Patience, N.J. Gooderham., A. Breadshaw, R. Cheingsong-Popov, J.N. Weber, D.S. Davies, G.M. Cook, R.J. Keynes and R.A. Weiss: Dextransulfate and fucoidan are potent inhibitors of HIV infection in vitro. Antiviral Chem. Chemotherapy, 2, 149-156 (1999).

36) T. Teruya, H. Tatemoto, T. Konishi and M. Tako: Structural characteristics and in vitro macrophage activation of acetyl fucoidan from Cladosiphon okamuranus. Glycoconjugate J., 26, 1019-1028 (2009).
養殖イトモズクから分離した

アルギン酸のレオロジー特性

照屋武志 ${ }^{1}$, 玉城志博1 ${ }^{1}$ 小西照子 ${ }^{1}$, 田幸正邦 ${ }^{1}$

${ }^{1}$ 琉球大学農学部生物資源科学科

(903-0213 沖縄県西原町字千原 1 番地)

沖縄県で，養殖により生産されたイトモズクからアル ギン酸 (Na 型) を分離精製 $(1.5 \%$, 湿潤藻体) して蒸留 水に溶解 $(90,150$ または $210 \mathrm{mg} / 20 \mathrm{~mL})$ し それに $\mathrm{NaCl}, \mathrm{KCl}$ および $\mathrm{CaCl}_{2}$ の混合液 (おのおの $30 \mathrm{mg}, 30$ $\mathrm{mg}$ および $30 \mathrm{mg} / 10 \mathrm{~mL}$; 最終塩濃度, それぞれ $0.1 \%)$ を 加え, レオゴニオメーターを使用して貯蔵弾性率 $\left(G^{\prime}\right)$ と 損失正接 $(\tan \delta)$ を測定した. $\mathrm{Na}$ 型のアルギン酸は $1.0 \%$ でも降伏值が認められず，擬塑性流動を示したが，混合 塩を添加したアルギン酸溶液は $0.3 \%$ 以上の濃度で降伏值 が認められ, 塑性流動を示し, 濃度の増大に伴って, 高 いずり応力にシフトした $\left(35^{\circ} \mathrm{C}\right)$. アルギン酸溶液の貯蔵 弾性率は, $0.3 \%$ で高い值を有し, 濃度の増大に伴って著 しく増大して $0.5 \%$, 室温で，ゲルを形成した。低温側で は $0.3 \%$ でゲル化した。貯蔵弾性率は温度の上昇に伴って 徐々に $50^{\circ} \mathrm{C}$ まで減少し, それ以上の温度で逆に増大し

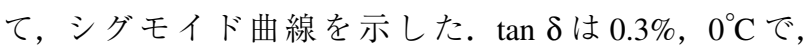
0.42 であったが， $0.7 \%$ では 0.18 に減少した。アルギン酸 溶液に尿素 $(4.0 \mathrm{M})$ を添加しても, 高い貯蔵弾性率に留 まった。また，本アルギン酸の貯蔵弾性率は中性からア ルカリ側で高い值を示したが，酸性側で著しく低い值に 留まった。イトモズクから分離したアルギン酸は, カル シウム $\left(\mathrm{Ca}^{2+}\right)$ と部分的に分子鎖内および分子鎖間架橋を 形成してゲル化することが推察された。 また，高い温度 で，L-グルロン酸の関与する疎水的相互作用により安定 な貯蔵弾性率を有することが考えられた。 